\title{
Diversity and distribution of arbuscular mycorrhizal fungi along a land use gradient in Terceira Island (Azores)
}

\author{
C. D. Melo ${ }^{1,2} \cdot$ R. Pimentel ${ }^{1} \cdot$ Christopher Walker $^{3,4} \cdot$ S. Rodríguez-Echeverría ${ }^{2} \cdot$ H. Freitas $^{2} \cdot$ P. A. V. Borges ${ }^{1}$
}

Received: 5 August 2019 / Revised: 2 April 2020 / Accepted: 6 April 2020

(C) German Mycological Society and Springer-Verlag GmbH Germany, part of Springer Nature 2020

\begin{abstract}
More knowledge of community composition of arbuscular mycorrhizal (AM) fungi in ecosystems in relation to habitat type and land use intensity is needed. We studied AMF in 106 soil samples from pristine natural forests and a gradient of disturbance including semi-natural and intensively managed pastures of Terceira, Azores. Altogether, 42 spore morphotypes were detected from eight AMF families, revealing different fungal community structures among the three land use types. Spore density was highest in native forests and lowest in intensively managed pastures, but fungal richness was highest in semi-natural pastures and lowest in native forests. No significant difference occurred between intensively managed pastures and native forests. Members of Acaulosporaceae and Glomeraceae were dominant in native forests, while fungi from Gigasporaceae and Claroideoglomeraceae were most abundant in semi-natural and intensively managed pastures respectively, indicating family-based ecological preferences. Rarefaction analysis revealed that pastures supported more diverse AMF communities than native forests, because in high elevation pristine forests, a few rare species dominate. It is therefore likely that more species would be found with increasing survey effort. Further research is needed to clarify the influence of land use type on AMF diversity and distribution in remote islands, and the role of native AMF on soil ecosystem processes and the spread of exotic plants.
\end{abstract}

Keywords Arbuscular mycorrhizal fungi $\cdot$ Diversity $\cdot$ Land use $\cdot$ Disturbance

\section{Introduction}

Arbuscular mycorrhizal fungi (AMF) comprise one of the most important groups of below ground biota (Jeffries et al. 2003; Barea et al. 2005). These obligate symbionts live in association with approximately $70 \%$ of vascular plants (Brundrett 2009). In this symbiosis, the plant supplies the

Section Editor: Marco Thines

C. D. Melo

cdrumonde73@gmail.com

$1 \mathrm{cE} 3 \mathrm{c}$ - Centre for Ecology, Evolution and Environmental Changes, Azorean Biodiversity Group, Departamento de Ciências e Engenharia do Ambiente, Universidade dos Açores, Rua Capitão João D’Ávila, 9700-042 Angra do Heroísmo, Açores, Portugal

2 CFE - Centre for Functional Ecology, Department of Life Sciences, University of Coimbra, 3001-401 Coimbra, Portugal

3 Royal Botanic Garden Edinburgh, 20A Inverleith Row, Edinburgh EH3 5LR, UK

4 School of Agriculture and Environment, University of Western Australia, 35 Stirling Highway, Crawley, Perth, WA 6009, Australia fungus with energy for its growth and reproduction via carbon compounds from photosynthesis, and the fungus provides the plant and soil with several benefits: AMF colonisation contribute to expand the nutrient depletion zone of plants and increase the uptake of water and the absorption of inorganic nutrients, such as phosphorus (Hu et al. 2009; Smith et al. 2010). Mycorrhizas may improve tolerance of crops to other forms of biotic stress, such as nematodes (Vos et al. 2012) and root pathogens (Pozo and Azcón-Aguilar 2007; van der Heijden et al. 2015), as well as to abiotic stresses, such as drought (Li et al. 2013; Chitarra et al. 2016) and metal toxicity (González-Chávez et al. 2004; Göhre and Paszkowski 2006). In addition, AMF accumulate carbon (Zhang et al. 2013) and contribute to the increase of microbial biomass in the soil, favouring the carbon sequestration process in the atmosphere. AMF also contribute to the formation and stability of soil aggregates by the production of glomalin (Rillig and Mummey 2006).

AMF are therefore beneficial for plant performance, playing a crucial role for the sustainability of natural and agricultural ecosystems (Barea et al. 2011), and important ecosystem services (Chen et al. 2018). However, the symbiotic 
benefits depend both on the host plant and the composition of the AMF community.

AMF communities vary in species composition and have an important role in the structuring and functioning of agroecosystems (Öpik et al. 2006). Several studies found that some factors such as soil characteristics and fertility (Minggui et al. 2012; Xiang et al. 2014), environmental conditions (Kivlin et al. 2011; Davison et al. 2015), plant community composition (Öpik et al. 2010; Moora et al. 2014) and agricultural activities can determine the local AMF communities (van der Gast et al. 2011; Avio et al. 2013; Köhl et al. 2014) by influencing the structure and function of symbiosis.

Land use changes are now playing unprecedented roles in shaping the environment of the planet, particularly after the mechanisation of agriculture and the creation of large areas of monocultures (Newbold et al. 2015). Moreover, land use changes can promote both taxonomic and functional homogenisation (Olden 2006) with a consequent loss of diversity at local scales. AMF respond differently to land use intensity (Mathimaran et al. 2007; Ciccolini et al. 2016), and several studies point out to a decrease on AMF diversity in agricultural soils compared to natural soils (Li et al. 2007; Alguacil et al. 2008; Verbruggen and Kiers 2010; Brito et al. 2012). The differences in richness observed between natural and cultivated systems are generally attributed to the selective pressure of agricultural activities, such as ploughing, fertilisation and application of fungicides (Jansa et al. 2002; EgertonWarburton et al. 2007). Consequently, the intensity of soil management could be an important factor determining the AMF occurrence and activity in agro systems (see also Faggioli et al. 2019).

The Azores archipelago has an extended area of grasslands (Martins 1993) including natural grasslands, semi-natural pastures and intensive pastures (Cardoso et al. 2009). In the last 600 years of human colonisation, Azorean native forests have been destroyed by human activities and replaced by agricultural land with massive impacts on species extinctions (Alcover et al. 2015; Terzopoulou et al. 2015) and likely loss of numerous endemic species in the near future (Triantis et al. 2010). These major land use changes and disturbances can significantly alter the level of plant community mycorrhisation and the proportion of different mycorrhizal types in a community (Gerz et al. 2016), and consequently affect the composition and dynamics of the AMF communities (Violi et al. 2008). Little is known on the AMF communities from Azores islands although a recent study has shown that AMF diversity in native forests is higher in islands with the least disturbance (Melo et al. 2017). Pasture management intensity has also been found to affect in Azores the composition and abundance of AMF communities, but not their diversity, in Azores (Melo et al. 2014).

Based on these previous studies, this work aimed to assess the influence of land use, from pristine forests to intensive pastures, in the composition and structure of AMF communities along a gradient of land use disturbance in Terceira Island, Azores. We predict that both species composition and diversity will be affected by historical land use changes with a homogenisation and loss of diversity in the most disturbed systems.

\section{Material and methods}

\section{Study sites}

All data used in this study come from surveys conducted in Terceira (Melo et al. 2014, 2017), a geologically recent volcanic island (0.4 Myr) of the Azorean archipelago (Ávila et al. 2016). The sampling areas were cattle-grazed upland pastures of two different types, and two fragments of native forests (Fig. 1). The two pasture types include semi-natural pastures with low grazing intensity and frequency (managed for more than 50 years, with a relatively high diversity of grasses and forbs) and intensively managed pastures with high grazing intensity and frequency (managed for more than 30 years, characterised by a depauperate vascular flora of five or fewer dominant species) (Melo et al. 2014). The semi-natural pastures, Pico Galhardo (SNP1) and Terra Brava (SNP2) (Fig. 1) that are included in Terceira Natural Park and are dominated by the perennial grasses Holcus lanatus and Agrostis castellana, have a high floristic diversity (Dias 1996; Borges 1997), often including other grasses such as Anthoxanthum odoratum, Lolium multiflorum, Holcus rigidus and Poa trivialis and non-forage species, including Lotus uliginosus, Rumex acetosella ssp. angiocarpus, Potentilla anglica, Hydrocotyle vulgaris, Plantago lanceolata and Lobelia urens (for more details, see Melo et al. 2014). The intensively managed pastures Agualva 1 (IMP1) and Agualva 2 (IMP2) (Fig. 1) resulted from the conversion of native forest to wood production and, finally, to permanent pastures and are surrounded by exotic eucalyptus plantation. The vegetation is dominated by Holcus lanatus and Lolium perenne but also have high populations of Trifolium repens (Borges 1997; Dias 1996) P. lanceolata, Cyperus esculentus, Mentha suaveolens, Cerastium fontanum and Rumex conglomeratus (Dias 1996; Borges 1997).

The native forests include two fragments from Terceira Natural Park-Pico Galhardo (NFT1) and Lagoinha (NFT2) (Melo et al. 2017), both dominated by the Azorean cedar $J$. brevifolia, a rare conifer endemic to the Azores, which dominates the high elevation (>650 m), with subdominant endemic woody perennials, including Laurus azorica (Lauraceae), Ilex perado azorica (Aquifoliaceae), Erica azorica (Ericaceae), Vaccinium cylindraceum (Ericaceae) and Frangula azorica (Rhamnaceae) (Elias et al. 2016). However, in Lagoinha, invasive woody species including C. japonica, Pittosporum undulatum (Pittosporaceae), 


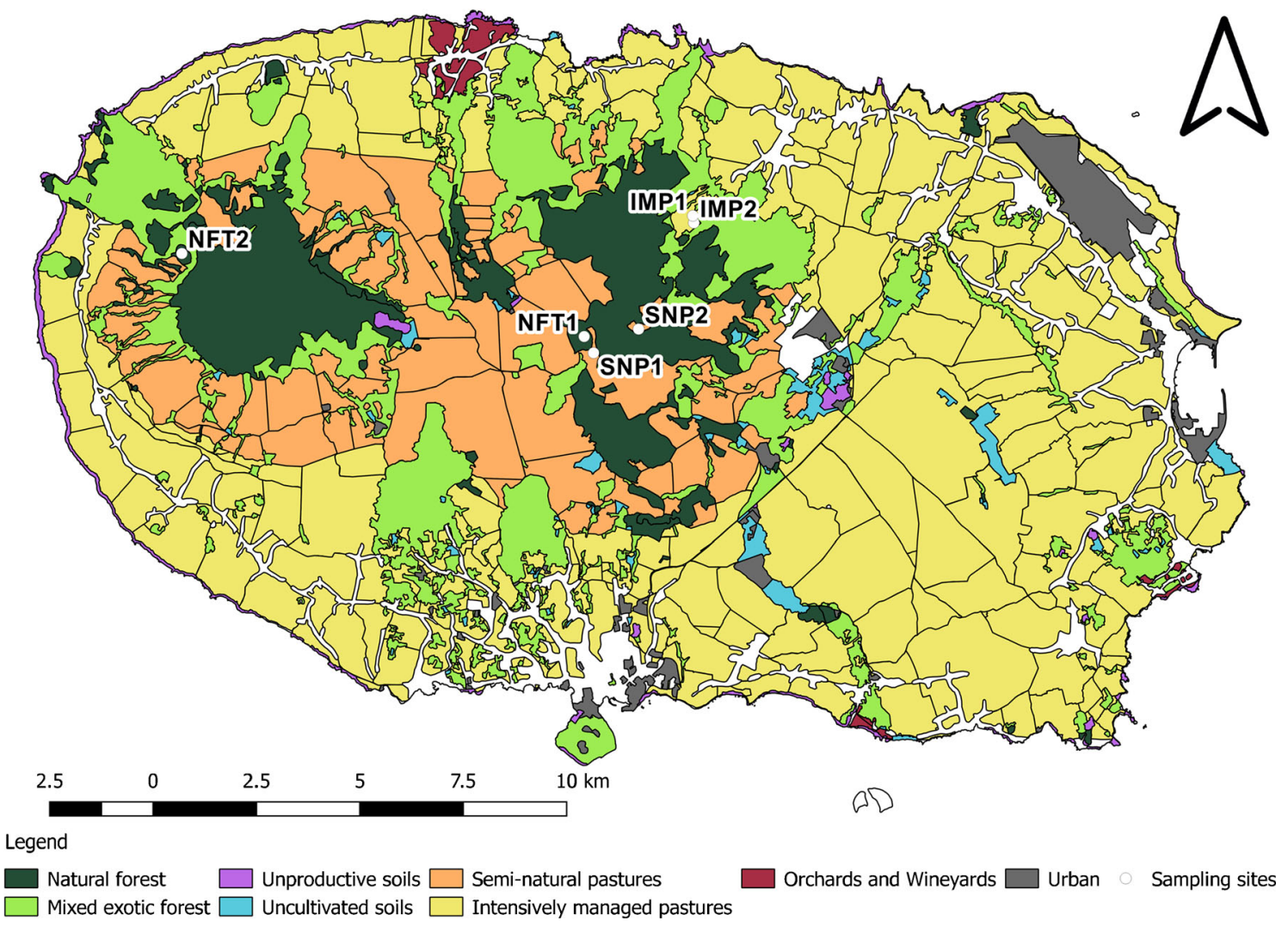

Fig. 1 Distribution of the three studied habitat types on Terceira Island

E. globulus and Acacia melanoxylon (Fabaceae) have begun to establish.

\section{Data analyses}

Spore density, species richness and occurrence were based on spores recovered directly from the soils. The ecological parameters were calculated as follows: Species richness was the number of taxa per sample found in a particular type of habitat (equivalent to alpha richness). Spore density was calculated as the number of spore of each taxon per $50 \mathrm{~g}$ of dried soil. Relative spore density (RD) was defined as the ratio of spore density of a particular taxon to the total density of glomeromycotan spores and it shows the degree of sporulation of different morphotypes in a given soil. Frequency (FR), reflecting distribution, was the percentage of samples in which a taxon or morphotype occurred among all samples, and it reflects the distribution status. The importance value (IV) was used to evaluate the dominance of taxa based on FR and $\mathrm{RD}$ and was calculated as $\mathrm{IV}=(\mathrm{FR}+\mathrm{RD}) / 2$. An IV $\geq$ $50 \%$ indicates that a taxon is dominant in terms of spore production; $10 \%<\mathrm{IV}<50 \%$ applies to common genera or species; an IV $\leq 10 \%$ indicates that a genus or species is rare (Chen et al. 2012).

We conducted different tests to analyse differences between habitat types. Spore density and species richness were not normally distributed, and data transformation was not suitable for parametric analysis application. Therefore data were compared by Kruskal-Wallis oneway analysis of variance by ranks and multiple comparisons between the samples with Mann-Whitney (Zar 1999). Statistical analysis was conducted with MINITAB Release 13.31 (Minitab 2000). Moreover, accumulation curves were constructed using EstimateS program v. 9.1.0 (Colwell 2013), with 100 runs, for the observed number of species and species richness estimates, using the nonparametric estimator Jackknife 1. Sampling completeness was calculated as the ratio of observed richness to estimated richness with both estimators, since both showed to be highly accurate and independent of scale (Hortal et al. 2006). Using EstimateS program v. 9.1.0 (Colwell 2013) and rarefaction techniques, common indices of diversity were also calculated for the three types of habitats (native forests, semi-natural pastures and intensively managed pastures), following the Hill series with four numbers: $q_{0}$ - species richness $(\mathrm{S}) ; q_{1}$-Shannon-Wiener $\left(\exp H^{\prime}\right)$; $q_{2}$-Simpson $(1 / D)$ and $q_{3}$-Berger-Parker index $(1 / d)$ (Magurran 2004). The rarefaction was set to 16 samples, the minimum number of samples available for both pasture types.

The compositional dissimilarity between all pairwise site comparisons was calculated using the recommended Bray- 
Curtis index (Clarke and Warwick 2001) with the $\log (x+1)$ including the density of each spore morphotype per sample in each site in the software 'Community Analysis Package v. 4.0' (CAP 4) (see http://www.pisces-conservation.com) (Seaby et al. 2004). Next, we evaluated habitat influence according to spatial scale by a simple multiple scale approach as used in other studies (Steffan-Dewenter et al. 2002; Schmidt et al. 2008). The habitat-type areas around each of the 6 sampling sites were analysed at ten scales, 100, 200, 400, 600, $800,1000,2000,3000,4000$ and $5000 \mathrm{~m}$, using Gaspar et al. (2008) land use layers and the QGIS v.2.18.12 (QGIS Development Team 2016). For each scale, we calculated the percentage area of each habitat surrounding the sampling site. Using SPSS v22 software (IBM Corp 2013), we calculated the Spearman rank correlation coefficient values between the species richness and spore density of the commonest families (Acaulosporaceae, Ambisporaceae, Claroideoglomeraceae, Gigasporaceae, Glomeraceae and Paraglomeraceae) at each site and the area corresponding to each habitat types, repeating the calculation for the ten different scales.

\section{Results}

A total of 21,624 glomeromycotan spores were extracted and classified from 106 field soil samples. Forty-two distinct morphotypes representing eight glomeromycotan families were detected, including nine undetermined glomoid morphotypes. Morphotypes placed in Glomeraceae (16), Acaulosporaceae (11), Gigasporaceae (4), Claroideoglomeraceae (3), Diversisporaceae (3), Ambisporaceae (2), Archaeosporaceae (2) and Paraglomeraceae (1) were recognised (Table 1).

\section{AMF richness and diversity}

The total AMF species richness changed significantly among the three types of land use (Kruskal-Wallis test; richness: $H=$ $15.05, p<0.01)$. AMF species richness was higher in seminatural pastures than in the native forests (Kruskal-Wallis test; richness: $H=14.18, p<0.001)$. However, no significant differences were found between intensively managed pastures and native forests. In fact, both intensive management pastures showed higher values of the second Hill number (exp Shannon-Wiener index) than both native sites (Table 2). However, Jackknife 1 showed that native forests, especially NFT1, may have more species than the other types of habitats (Table 2). In addition, completeness showed high values for all pastures but low for native forests suggesting that more species are expected to be found in this habitat, which was confirmed by the species rarefaction curves (Table 2). On the other hand, the fourth Hill number (Berger-Parker index (1/d)) shows lower values, indicating that native forests are dominated by few species which could contribute to lower values of the second to fourth Hill numbers (Table 2). Moreover, based on the IV, the native forests showed the highest values (Table 1). NFT1 was dominated by A. lacunosa $(\mathrm{RD}=27.13$, $\mathrm{FR}=100, \mathrm{IV}=63.56)$ followed by Acaulospora sp. $1(\mathrm{RD}=$ $15.65, \mathrm{FR}=100, \mathrm{IV}=57.82$ ), while NFT2 was dominated by A. brasiliensis $(\mathrm{RD}=31.40, \mathrm{FR}=100, \mathrm{IV}=65.70)$ and Glomeraceae sp. $(\mathrm{RD}=30.38, \mathrm{FR}=100, \mathrm{IV}=50.90)$ (Table 1). In contrast, in semi-natural pastures especially in SNP1, A. laevis was the most abundant and frequently AMF species $(\mathrm{RD}=29.37, \mathrm{FR}=100, \mathrm{IV}=64.69)$ followed by A. paulinae $(\mathrm{RD}=12.96, \mathrm{FR}=93.75, \mathrm{IV}=53.35)$ and S. calospora $(\mathrm{RD}=15.77, \mathrm{FR}=87.50, \mathrm{IV}=51.63)$ whereas SNP2 is dominated only by $S$. calospora $(\mathrm{RD}=64.33, \mathrm{FR}=$ 87.50, IV =75.91) (Table 1$)$. Both intensively managed pastures were dominated by $C$. etunicatum (IMP1: RD $=32.96$, $\mathrm{FR}=100, \mathrm{IV}=66.48 ; \mathrm{IMP} 2: \mathrm{RD}=32.29, \mathrm{FR}=100, \mathrm{IV}=$ 66.14) (Table 1).

\section{AMF density and composition}

AMF spore density also varied significantly among the three land use types (Kruskal-Wallis test; density: $H=78.13$, $p<0.001)$. AMF spore density was highest in native forests and lowest in intensively managed pastures types (KruskalWallis test; density: $H=53.78, p<0.001)$.

Significant differences between land use types were found in the AMF species richness for the 6 commonest taxa (Kruskal-Wallis test; Acaulosporaceae: $H=26.30, p<0.001$; Ambisporaceae: $H=21.38, p<0.001$; Claroideoglomeraceae: $H=96.34, p<0.001$; Gigasporaceae: $H=71.41, p<0.001$; Glomeraceae: $H=21.92, p<0.001$; Paraglomeraceae: $H=$ $42.03, p<0.001$ ) and in the AMF spore density (KruskalWallis test; Acaulosporaceae: $H=67.70, p<0.001$; Ambisporaceae: $H=21.02, p<0.001$; Claroideoglomeraceae: $H=88.33, p<0.001$; Gigasporaceae: $H=72.14, p<0.001$; Glomeraceae: $H=81.77, p<0.001$; Paraglomeraceae: $H=$ $42.25, p<0.001)$. Indeed, native forests harboured a significantly higher density of Acaulosporaceae and Glomeraceae taxa than the remaining habitat types (Fig. 2a, b). However, no differences were found in Acaulosporaceae richness between native forests and semi-natural pastures, or in Glomeraceae richness between native forests and intensively managed pastures (Fig. 2a). Semi-natural pastures showed the highest AMF species richness and spore density belonging to Ambisporaceae, and the intensively managed pastures presented the lowest of both parameters (Fig. 2a, b). No differences were found in AMF species richness and spore density of Ambisporaceae between native forests and intensively managed pastures (Fig. 2a, b).

Gigasporaceae showed the same pattern, i.e. richness and density were highest in semi-natural pastures and lowest in native forests (Fig. 2a, b). On the other hand, the intensively managed pastures harboured a significantly higher richness 


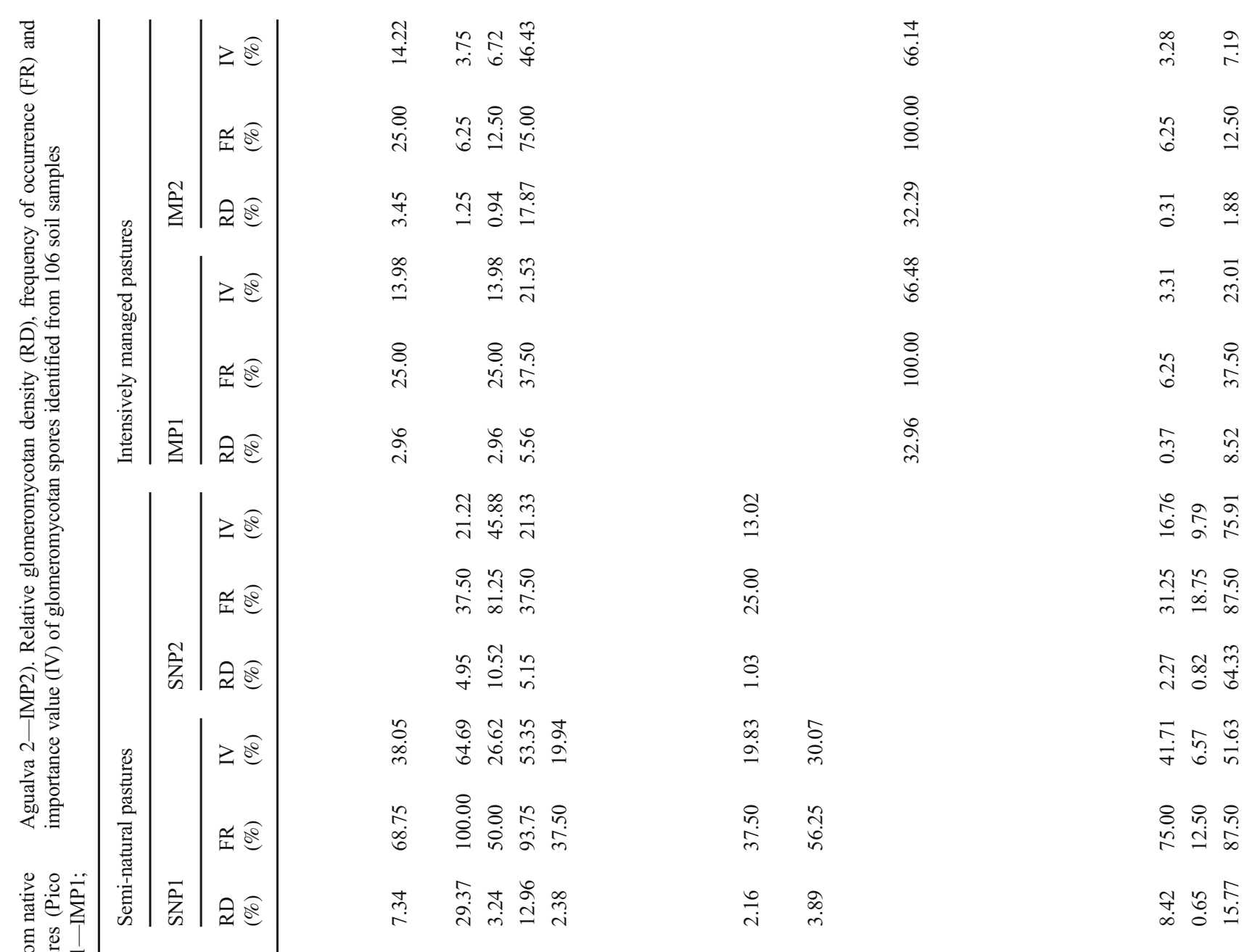




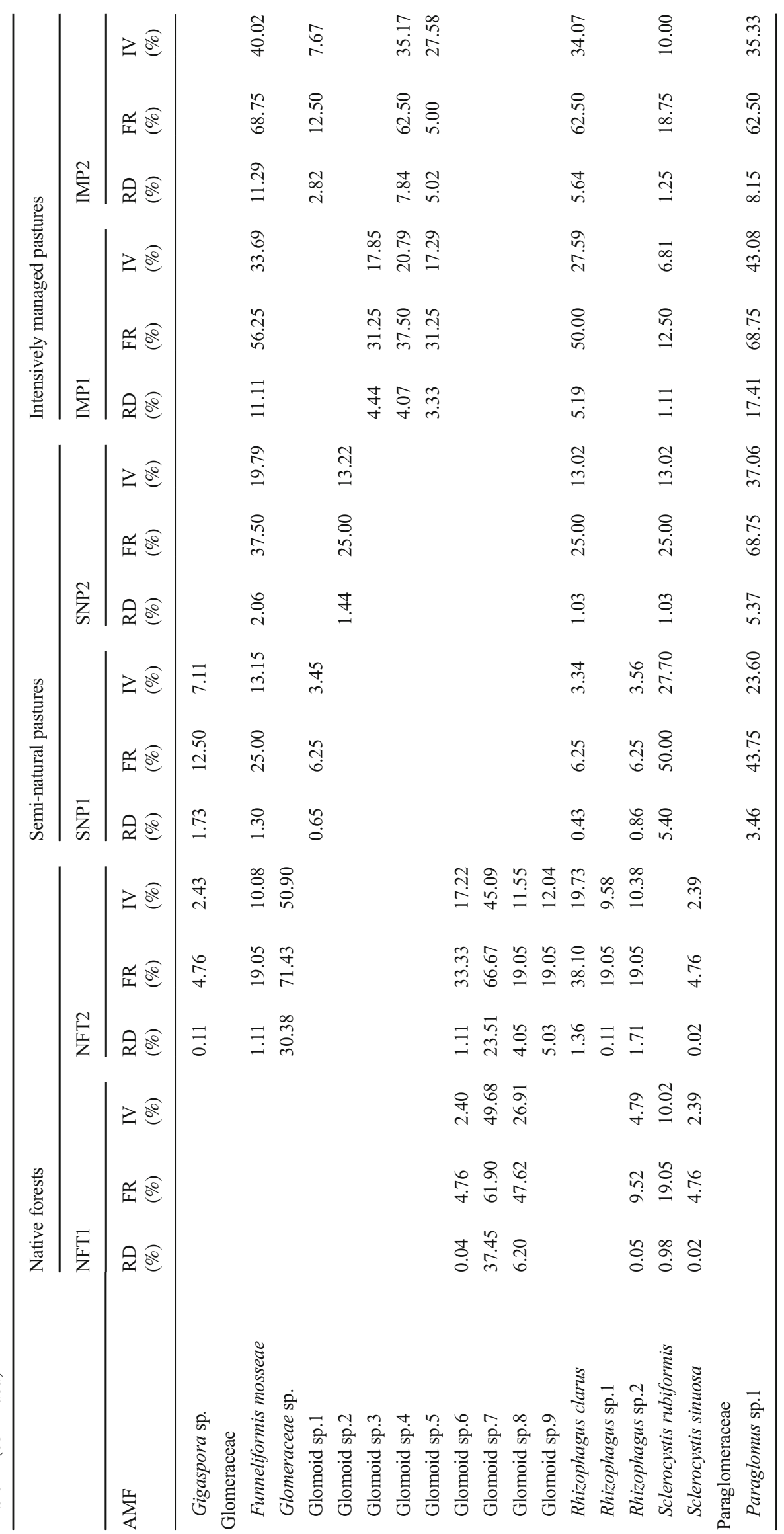


Table 2 Hill diversity metrics for the three types of habitats: native forests of Terceira (Pico Galhardo-NFT1; LagoinhaNFT2), semi-natural pastures (Pico Galhardo-SNP1; Terra Brava-SNP2) and intensively managed pastures (Agualva 1IMP1; Agualva 2-IMP2). Number of individuals $(N)$; number of species $\left(q_{0}=S\right)$; Jackknife 1; Completeness; Species rarefaction ( $q_{0}$ rarefaction, S Raref); Shannon-Wiener index $\left(q_{1}-\right.$ Exp $\left.H^{\prime}\right)$; Simpson index $\left(q_{2}-1 / D\right)$; Berger-Parker index $\left(q_{3}-1 / d\right)$

\begin{tabular}{|c|c|c|c|c|c|c|}
\hline \multirow[b]{2}{*}{ Indices } & \multicolumn{2}{|c|}{ Native forests } & \multicolumn{2}{|c|}{ Semi-natural pastures } & \multicolumn{2}{|c|}{ Intensively managed pastures } \\
\hline & NFT1 & NFT2 & SNP1 & SNP2 & IMP1 & IMP2 \\
\hline$N$ & 10,691 & 9398 & 463 & 485 & 270 & 319 \\
\hline$S$ & 20 & 14 & 17 & 12 & 13 & 14 \\
\hline Jackknife 1 & 28.57 & 17.81 & 19.81 & 12 & 13.94 & 15.88 \\
\hline Completeness & 0.70 & 0.79 & 0.86 & 1.00 & 0.93 & 0.88 \\
\hline S Raref & 16.9 & 13.04 & 17 & 12 & 13 & 14 \\
\hline Shannon $\left(\operatorname{Exp} \mathrm{H}^{\prime}\right)$ & 4.88 & 4.84 & 9.54 & 4.00 & 8.16 & 8.15 \\
\hline Simpson (1/D) & 3.96 & 3.93 & 6.72 & 2.30 & 5.85 & 5.88 \\
\hline Berger-Parker (1/d) & 2.67 & 3.18 & 3.40 & 1.57 & 3.23 & 3.28 \\
\hline
\end{tabular}

and density of Claroideoglomeraceae and Paraglomeraceae taxa than the remaining habitat types (Fig. 2a, b).

However, no differences were found in Claroideoglomeraceae richness and density between native forests and semi-natural pastures as well as in Paraglomeraceae richness and density between the two pasture types. These differences in AMF spore density revealed distinct assemblages in AMF community composition (Fig. 3). Along with the log-linear analysis, the first axis of BrayCurtis-based NMDS analysis clearly separated the native forest sites (NFT1; NFT2) from the two types of pastures, while the second axis showed differences in glomeromycotan composition between sites within the same land use type for semi-natural pastures and native forests.

\section{The influence of land use at different spatial scales}

AMF richness and density of the commonest families were influenced by habitat types at different spatial scales. The density of Acaulosporaceae members was significantly and positively correlated with the area of the native forests up to $400 \mathrm{~m}$, and above $600 \mathrm{~m}$ with semi-natural pastures (Fig. 4a). Intensively managed pastures always presented a negative correlation with the density of this AMF group, as well as the exotic forest but only above $400 \mathrm{~m}$ (Fig. 4a). On the other hand, Acaulosporaceae richness was positively correlated only with semi-natural pastures for all considered scales and negatively correlated with exotic forest, but only from 200 to $5000 \mathrm{~m}$, and intensively managed pastures, (Fig. 4b). The density of Ambisporaceae members was positively correlated with the area of semi-natural pastures and negatively correlated with intensively managed pastures for all considered scales in both habitat types (Fig. $4 c)$. The density of this AMF group also showed a positive correlation with the area of native forests from 400 to $600 \mathrm{~m}$ and above $4000 \mathrm{~m}$ (Fig. 4c). The exotic forest also presented a negative correlation with the density of this AMF group, but only above $400 \mathrm{~m}$ (Fig. 4c). The same result pattern was shown for the richness of this AMF family (Fig. 4d). As for the Claroideoglomeraceae family, either density or richness was negatively correlated with semi-natural pastures, but when the area of this habitat type was estimated at distances above $400 \mathrm{~m}$ or greater than $4000 \mathrm{~m}$ for density and richness, respectively (Fig. 4e, f). Intensively managed pastures presented a positive correlation with the density of members of Claroideoglomeraceae from 100 to $1000 \mathrm{~m}$ and at $4000 \mathrm{~m}$, while its richness showed a positive correlation with this habitat type from 600 to $1000 \mathrm{~m}$ (Fig. 4e, f). The density of this AMF family also showed a positive correlation with the area of exotic forest from 400 to $600 \mathrm{~m}$ and at $3000 \mathrm{~m}$ (Fig. 4e). The density and richness of Gigasporaceae members were positively correlated with the area of semi-natural pastures but only for the first $100 \mathrm{~m}$ (Fig. 4g, h). The richness of this AMF group also showed a negative correlation with the area of native forests from 100 to $200 \mathrm{~m}$ (Fig. 4h). The exotic forest was positively correlated with the density and richness of Glomeraceae members from 200 to $600 \mathrm{~m}$ and from 200 to $1000 \mathrm{~m}$, respectively (Fig. 4i, j). However, the richness of this AMF group was negatively correlated with the increased area of the semi-natural pastures until $400 \mathrm{~m}$ and also with the area of native forests from 600 to $4000 \mathrm{~m}$ (Fig. 4j). The intensively managed pastures always presented a positive correlation with the density and richness of Paraglomeraceae members (Fig. 4k, m). The same result was also shown for the area of the exotic forest but only above 200 and $400 \mathrm{~m}$ for density and richness, respectively (Fig. 4k, $\mathrm{m})$. The semi-natural pastures and the native forests were negatively correlated with the density of this AMF group from 200 to $400 \mathrm{~m}$ (Fig. 4k), while its richness showed a negative correlation with increased area of semi-natural pastures above $200 \mathrm{~m}$ as well as with the area of native forests but only at 200 and $5000 \mathrm{~m}$ (Fig. 41). 
Fig. 2 a AMF species richness and $\mathbf{b}$ density of each family of Glomeromycota in each habitat type: native forests (NFT; median, $N=42)$, semi-natural pastures (SNP; median, $N=32$ ) and intensively managed pastures (IMP; median, $N=32$ ) for members of the families

Acaulosporaceae,

Ambisporaceae,

Claroideoglomeraceae,

Gigasporaceae, Glomeraceae and Paraglomeraceae. Different letters above each bar indicate significant differences in AMF species richness and density among the three type of land uses (MannWhitney test, $p<0.05$ )
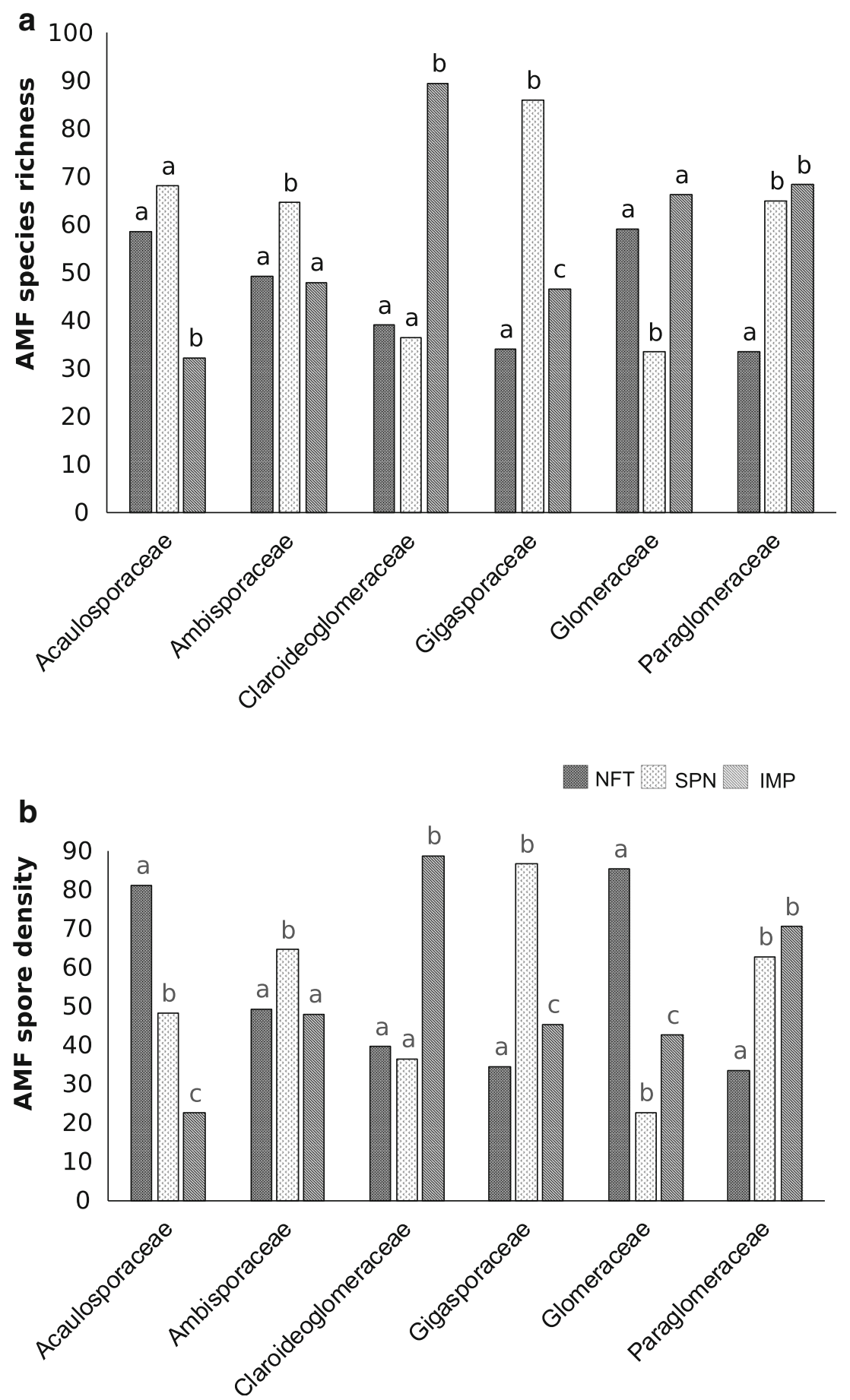

\section{Discussion}

There was a clear distinction between the communities of native forests and agricultural areas. Further distinctions between AMF communities could be explained by agricultural practices, with more intensive production systems having both more specialised AMF composition and reduced AMF diversity and density when compared with more extensive or pastoral production systems (van der Gast et al. 2011; Lin et al.
2012; Melo et al. 2014; Kim et al. 2015). The current study showed that native forests presented the highest AMF spore density which is in accordance with other studies in natural communities (Öpik et al. 2006; Dobo et al. 2016; Birhane et al. 2018). This suggests that despite the low turnover rates of fine roots in mature forest, the diversity and richness of plants in this habitat could play an important role in determining AMF spore density (Mafaziya and Madawala 2015; Birhane et al. 2018). Furthermore, in the harsh environment 
of mountain ecosystems, plants tend to be more dependent on soil microorganism such as mycorrhizal fungi, a dependency that might contribute to the increase of AMF spore density in natural forests (Birhane et al. 2018). Contrary to the results showed by Melo et al. (2014) based on trap cultures data, AMF species richness was higher in semi-natural pastures than in intensively managed pastures, showing that although measures of diversity estimated by trap culture may not represents the field situation they could provide a more complete picture of AMF communities (Brundrett et al. 1999; Hijri et al. 2006; Wang et al. 2008). Interestingly, AMF species richness did not change between intensively managed pastures and native forests, suggesting that vegetation cover (Ndoye et al. 2012; Birhane et al. 2018) and level of disturbance may play a role in determining the abundance and richness of AMF species (Mafaziya and Madawala 2015).

Disturbance can play a key role in AMF diversity and composition depending on the type and severity of the disturbance that alter soil characteristics (Xiang et al. 2014), such as tillage (Alguacil et al. 2008), fertilisation (Egerton-Warburton et al. 2007; Lin et al. 2012; Zheng et al. 2014), ploughing (Jansa et al. 2006; Alguacil et al. 2014) and crop rotation (Castillo et al. 2006; Verbruggen and Kiers 2010). Agriculture in the studied areas is characterised by low inputs of fertiliser and less intensive management, with reduced tillage or no tillage compared with intensive agriculture in other European regions. This could explain the absence of differences in the AMF species richness between intensively management pastures and native forests. Álvarez-Sanchéz et al. (2012) in a database study from Mexico and USA, with eight different vegetation types and land uses, showed that low levels of disturbance did not reduce species richness in either the Mexican or the USA sites, and in the Mexican dataset, species richness and diversity increased where disturbance was low. A similar result was also found by $\mathrm{Xu}$ et al. (2017) in a study among three land use types (forest, grassland and arable fields) in China. They argued that the similarity in AMF diversity between arable land and forest could be explained by the reduced inputs of fertiliser and by the low level of land use intensity.

Previous studies have shown that the plant identity (Bainard et al. 2014; Zheng et al. 2016), diversity and richness (De Deyn et al. 2011; Lekberg and Waller 2016), as well as plant functional group (König et al. 2010; Sun et al. 2013) may play a critical role in deciding AMF diversity and composition (Johnson et al. 1992; Yang et al. 2012). The lowest AMF richness in the native forests could be explained by the relatively high plant diversity in pastures, because diverse plant species provide more niches hosting AMF. A similar result was also found by Solís-Rodríguez et al. (2020) in a diversity and distribution study of AMF in tropical low flooding forest (TLFF) of Yucatan, Mexico. They observed that the AMF diversity was significantly related to the diversity, abundance, richness and cover of the herbaceous vegetation, while the abundance of spores is related to basal area and abundance of trees.

Plant species may allocate various qualitative and quantitative carbon resources to their AMF partners (Jamshidi et al. 2015) or supply various root exudates; consequently, distinct rhizospheric aspects in terms of physical, chemical or biological conditions occur (Zangaro et al. 2008; Lazarevic et al. 2018). Dominant perennial grasses in pastureland systems such as H. lanatus, A. castellana and L. perenne have a high $\mathrm{C}$ investment enabling the high turnover of fines roots, which may encourage a more diverse AMF community and might improve nutrient uptake to the benefit of fast-growing plant species. König et al. (2010) showed that AMF sequence

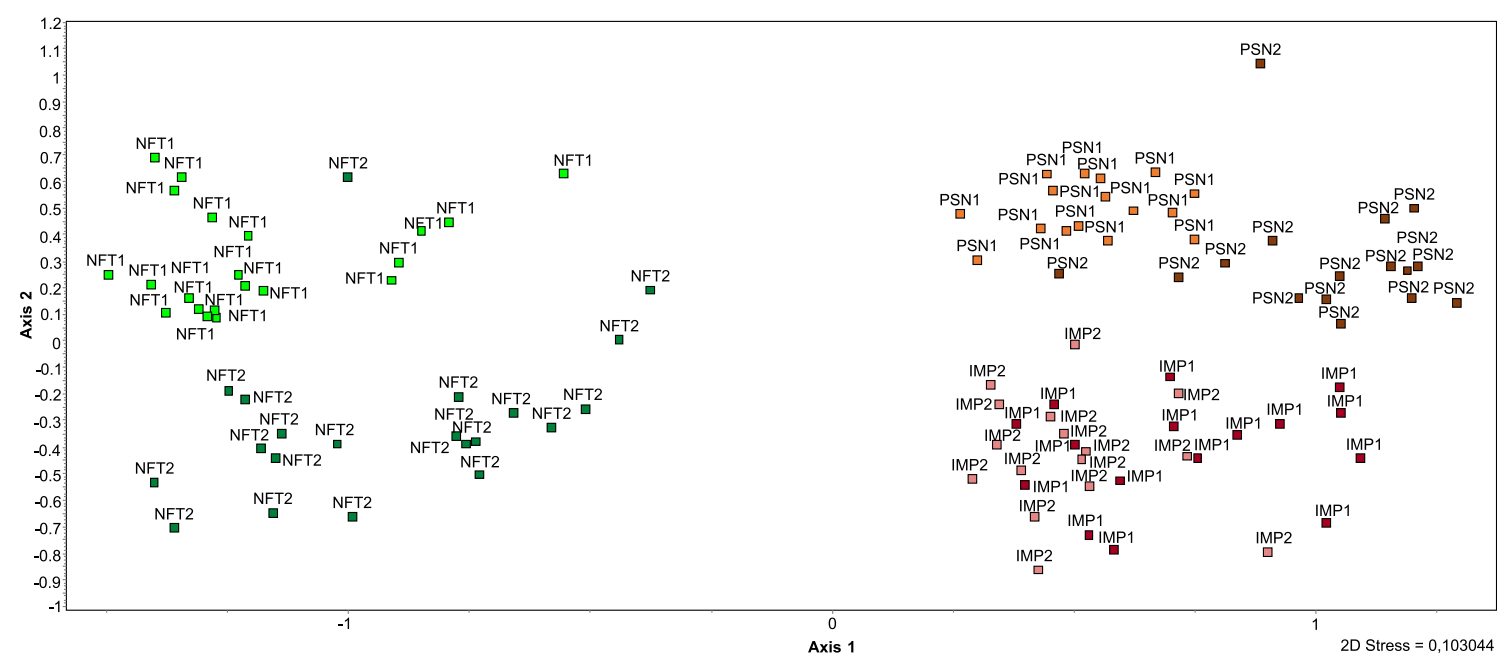

Fig. 3 Nonmetric Dimensional Scaling (NMDS) with Bray-Curtis similarities for glomeromycotan community composition between native forests from (NFT1 — white green squares; NFT2 — dark green squares), semi-natural pastures (SNP1 - orange squares; SNP2 - brown squares) and intensively managed pastures (IMP1— dark pink squares; IMP2white pink squares), using all data (106 soil samples) 
Fig. 4 Variation in the Spearman rank correlation values between AMF species richness and density and the area of the three habitat types across ten increasing scales for each family of Glomeromycota. Circles represent native forests, triangles are exotic forest, diamonds are semi-natural pastures and squares represent intensively managed pastures

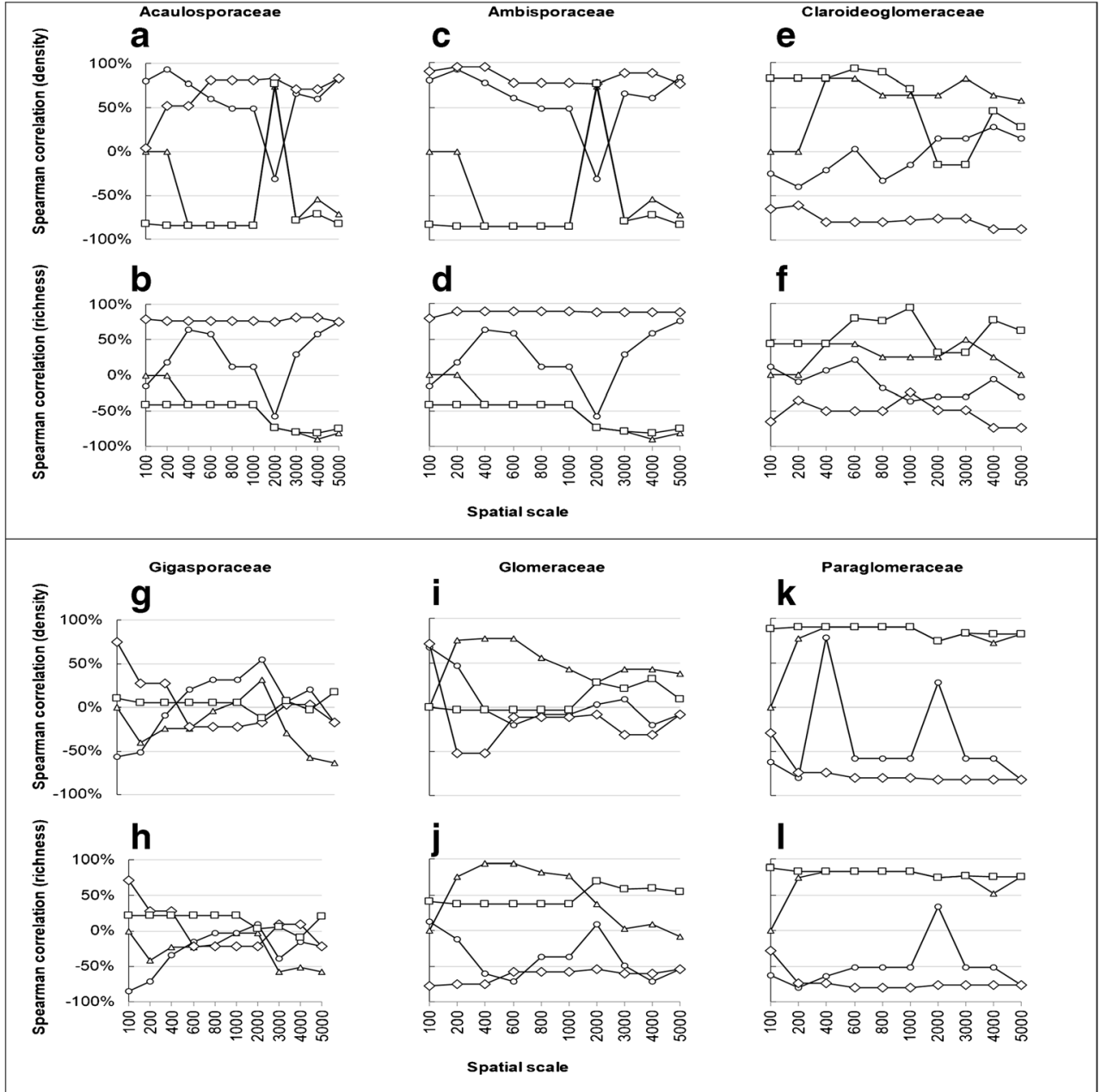

richness was influenced by plant richness, and the presence of grasses as plant functional group favoured the AMF richness at the Jena Experiment site. Dai et al. (2013) also examined the AMF communities in wheat-growing cropland, natural areas and semi-natural areas along roads. The authors argue that the broad range of spatial and temporal niches in roadsides planted with a persistent grass species could explain the higher AMF abundance and diversity in this land use type than in cropland, which is homogenous across the landscape, and in natural areas, which are homogeneous within a site.

The relatively lower diversity of AMF in forests compared to grassland is in accordance with other studies (Belay et al. 2015; Davison et al. 2015; Xu et al. 2017). Although, native forests are dominated by $J$. brevifolia, the low diversity of AMF plants in these sites and the presence of the other shrubs (Vaccinium cylindraceum; Erica azorica) or trees (Pittosporum undulatum; Eucalytus globulus) with different mycorrhizal associations (ectomycorrhiza; ericoid mycorrhiza) could explain the lower AMF diversity. Lumini et al. (2010) also observed that the lowest numbers of AMF OTUs in natural ecosystems could be due to the presence of Erica arborea, Arbutus unedo and Quercus suber, i.e. plant species with similarly different mycorrhizal associations. Moreover, based on Hill numbers, native forests also showed the lowest AMF diversity, which could be explained by high dominance of few species that display adaptive strategies to live with hosts in the harsh environment conditions of mountain habitats (Velázquez et al. 2013; Senés-Guerrero and Schüßler 2016). Acaulosporaceae are dominant members of native forests, this could be explained by the potential effect of high OM content, soil available $\mathrm{N}$ and lower $\mathrm{pH}$ (Bainard et al. 2014; Melo et al. 2019) that characterise this land use type (Melo et al. 2017) comparatively with the other two type of pastures (Melo et al. 2014). In addition, Acaulosporaceae is well documented as occurring in protected areas, representing $75.7 \%$ of all the species described so far (Turrini and Giovannetti 2012).

For example, Velázquez et al. (2013) in El Palmar National Park (Argentina) found that Acaulosporaceae were the most widespread and abundant (49\% of spores) Glomeromycota, followed by the Glomeraceae $(40 \%)$ and Gigasporaceae (6\%). Also, Shi et al. (2014) showed that Acaulospora was the most abundant genus along altitudinal gradients on $\mathrm{Mt}$. Taibai of the Qinling Mountains. However, an unexpected 
finding was the positive correlation of density and richness from members of Gigasporaceae with the increase of the semi-natural pastures area, whereas this family is not usually detected in disturbed field agricultural soils (Jansa et al. 2003; Mathimaran et al. 2007). This result is in agreement with those of Boriello et al. (2012) who find many sequences related to Gigasporaceae in maize fields under a different level of tillage and $\mathrm{N}$ fertilisation, and also with the results of Oehl et al. $(2005,2010)$ based on spore identification from field samples. Also, Cai et al. (2014) found that A. laevis and S. calospora, AMF species that frequently occur in less disturbed habitats, had very strong adaptability, and were also distributed in natural grassland and all types of degraded grasslands. Although inconsistent with other previous studies showing a decline of AMF diversity with the land use intensification (Schneider et al. 2010; Schnoor et al. 2011; Hartmann et al. 2015), our result suggest that different AMF species have different responses and sensitivity to grassland disturbance in different ecosystems.

The predominance of species belonging to Glomeraceae confirms the well-known characteristics of the members of this family, adaptability and stress tolerance, and that they can be retrieved across a wide range of habitats, either natural or agricultural (Öpik et al. 2006), such as agricultural landscapes (Alguacil et al. 2008; Xiang et al. 2014), restored seminatural grasslands (Schnoor et al. 2011) and coastal sand dunes (Kawahara and Ezawa 2013).

It is also interesting to note the relatively high density and richness of members of the Paraglomeraceae in intensively managed pasture. Species in this family have not been recorded to sporulate densely in other tropical and temperate grasslands (Hijri et al. 2006; Moora et al. 2014; Xiang et al. 2014). The high spore population of Paraglomeraceae in exotic forest land in the Azores may imply adaptability to different levels of soil disturbance. Rodríguez-Echeverría et al. (2017) also found that Paraglomeraceae was the most abundant family in Gorongosa National Park (GNP) grasslands. A study with maize under conventional and no-tillage systems in fertilised and unfertilised soils found some sequences related to Paraglomeraceae in all soil management conditions (Boriello et al. (2012).

\section{Conclusion}

This study confirms that the conversion of native forests to pasturelands modifies the structure of AMF communities in a remote volcanic oceanic island. These findings raise interesting questions about the dispersal and colonisation of islands by AMF and about the ecological specificity and role of AMF in different island habitats. Importantly, the low input pasture management used in this island seems to help preserving AMF diversity but the unique diversity of native forests might be in danger from the reduction of forest patches and the expansion of exotic plant species.

Acknowledgements The authors would like to thank to the Regional Directorate for Forest Resources for field sites support.

Availability of data and materials All data generated or analysed during this study are included in this published article.

Adherence to national and international regulations Not applicable.

Author contributions Conceptualisation, CDM; investigation, CDM; AMF identification, CDM and CW; formal analysis, CDM, RP and PAVB; writing - original draft preparation, CDM and RP; writingreview and editing, CDM, RP, CW, SR-E, HF and PAVB; and PAVB and HF supervised the development of this work. All authors interpreted the results and contributed to the final manuscript and CDM led the writing of the manuscript. All authors gave final approval for publication.

Funding information This research was funded by Fundo Regional para a Ciência e Tecnologia-Governo dos Açores (M3.1.a/F/059/2016; M3.1.a/F/012/2016) and by the Development Grant (IF/00462/2013) from the Fundação para a Ciência e a Tecnologia (FCT) Portugal with national funds and co-funded by FEDER and COMPETE 2020 program. The Royal Botanic Garden Edinburgh (RBGE) is supported by the Scottish Government's Rural and Environmental Science and Analytical Services Division.

\section{Compliance with ethical standards}

Conflict of interest The authors declare that they have no conflict of interest.

Ethics approval and consent to participate Not applicable.

Consent for publication Not applicable.

\section{References}

Alcover JA, Pieper H, Pereira F et al (2015) Five new extinct species of rails (Aves: Gruiformes: Rallidae) from the Macaronesian Islands (North Atlantic Ocean). Zootaxa 4057:151-190. https://doi.org/10. 11646/zootaxa.4057.2.1

Alguacil MM, Lumini E, Roldan A et al (2008) The impact of tillage practices on arbuscular mycorrhizal fungal diversity in subtropical crops. Ecol Appl 18:527-536. https://doi.org/10.1890/07-0521.1

Alguacil MM, Torrecillas E, García-Orenes F, Roldán A (2014) Changes in the composition and diversity of AMF communities mediated by management practices in a Mediterranean soil are related with increases in soil biological activity. Soil Biol Biochem 76:34-44. https://doi.org/10.1016/j.soilbio.2014.05.002

Álvarez-Sánchez J, Johnson NC, Antoninka A et al (2012) Large-scale diversity patterns in spore communities of arbuscular mycorrhizal fungi. In: Pagano M (ed) Mycorrhiza: occurrence in natural and restored environments. Nova Science Publishers, New York, pp $29-47$

Ávila SP, Melo C, Berning B et al (2016) Persististrombus coronatus (Mollusca: Strombidae) in the lower Pliocene of Santa Maria Island (Azores, NE Atlantic): paleoecology, paleoclimatology and paleobiogeographic implications. Palaeogeogr Palaeocl 441:912923. https://doi.org/10.1016/j.palaeo.2015.10.043 
Avio L, Castaldini M, Fabiani A et al (2013) Impact of nitrogen fertilization and soil tillage on arbuscular mycorrhizal fungal communities in a Mediterranean agroecosystem. Soil Biol Biochem 67:285-294. https://doi.org/10.1016/j.soilbio.2013.09.005

Bainard LD, Bainard JD, Hamel C et al (2014) Spatial and temporal structuring of arbuscular mycorrhizal communities is differentially influenced by abiotic factors and host crop in a semi-arid prairie agroecosystem. FEMS Microbiol Ecol 88:333-344. https://doi.org/ $10.1111 / 1574-6941.12300$

Barea JM, Palenzuela J, Cornejo P et al (2011) Ecological and functional roles of mycorrhizas in semi-arid ecosystems of Southeast Spain. J Arid Environ 75:1292-1301. https://doi.org/10.1016/j.jaridenv. 2011.06.001

Barea JM, Pozo MJ, Azcón R, Azcón-Aguilar C (2005) Microbial cooperation in the rhizosphere. J Exp Bot 56:1761-1778. https://doi. org/10.1093/jxb/eri197

Belay Z, Vestberg MV, Assefa F (2015) Diversity and abundance of arbuscular mycorrhizal fungi across different land use types in a humid low land area of Ethiopia. Trop Subtrop Agroecosystems 18:47-69

Birhane E, Fatumah N, Gidey K et al (2018) Vegetation cover density and disturbance affected arbuscular mycorrhiza fungi spore density and root colonization in a dry Afromontane forest, northern Ethiopia. J For Res 29:675-686. https://doi.org/10.1007/s11676-017-0493-5

Borges PAV (1997) Pasture arthropod community structure in Azorean islands of different geological age. Ph.D. Dissertation, Imperial College, University of London, London

Borriello R, Lumini E, Girlanda M et al (2012) Effects of different management practices on arbuscular mycorrhizal fungal diversity in maize fields by a molecular approach. Biol Fertil Soils 48:911922. https://doi.org/10.1007/s00374-012-0683-4

Brito I, Goss MJ, de Carvalho M et al (2012) Impact of tillage system on arbuscular mycorrhiza fungal communities in the soil under Mediterranean conditions. Soil Tillage Res 121:63-67. https://doi. org/10.1016/j.still.2012.01.012

Brundrett MC (2009) Mycorrhizal associations and other means of nutrition of vascular plants: understanding the global diversity of host plants by resolving conflicting information and developing reliable means of diagnosis. Plant Soil 320:37-77. https://doi.org/10.1007/ s11104-008-9877-9

Brundrett MC, Abbott LK, Jasper DA (1999) Glomalean mycorrhizal fungi from tropical Australia. I. Comparison of the effectiveness and specificity of different isolation procedures. Mycorrhiza 8: 305-314. https://doi.org/10.1007/s005720050251

Cai X-B, Peng Y-L, Yang M-N, et al (2014) Grassland degradation decrease the diversity of arbuscular mycorrhizal fungi species in Tibet Plateau. Not Bot Horti Agrobot Cluj-Napoca 42. doi: https://doi.org/ 10.15835/nbha.42.2.9458

Cardoso P, Lobo JM, Aranda SC et al (2009) A spatial scale assessment of habitat effects on arthropod communities of an oceanic island. Acta Oecol 35:90-597. https://doi.org/10.1016/j.actao.2009.05.005

Castillo CG, Rubio R, Rouanet JL, Borie F (2006) Early effects of tillage and crop rotation on arbuscular mycorrhizal fungal propagules in an Ultisol. Biol Fertil Soils 43:83-92. https://doi.org/10.1007/s00374005-0067-0

Chen K, Weixin L, Guo S et al (2012) Diversity of arbuscular mycorrhizal fungi in continuous cropping soils used for pepper production. Afr J Microbiol Res 6:2469-2974. https://doi.org/10.5897/ AJMR11.1532

Chen M, Arato M, Borghi L, et al (2018) Beneficial services of arbuscular mycorrhizal fungi-from ecology to application. Front Plant Sci 9: 1270 https://doi.org/10.3389/fpls.2018.01270

Chitarra W, Pagliarani C, Maserti B et al (2016) Insights on the impact of arbuscular mycorrhizal symbiosis on tomato tolerance to water stress. Plant Physiol 171:1009-1023. https://doi.org/10.1104/pp. 16.00307
Ciccolini V, Ercoli L, Davison J et al (2016) Land-use intensity and host plant simultaneously shape the composition of arbuscular mycorrhizal fungal communities in a Mediterranean drained peatland. FEMS Microbiol Ecol:92. https://doi.org/10.1093/femsec/fiw186

Clarke KR, Warwick RM (2001) Change in marine communities: an approach to statistical analysis and interpretation, second edn. PRIMER-E, Plymouth, UK

Colwell RK (2013) EstimateS: statistical estimation of species richness and shared species from samples. Version 9. User's Guide and application published at: http://purl.oclc.org/estimates

Dai M, Bainard LD, Hamel C et al (2013) Impact of land use on arbuscular mycorrhizal fungal communities in rural Canada. Appl Environ Microbiol 79:6719-6729. https://doi.org/10.1128/AEM. 01333-13

Davison J, Moora M, Öpik M et al (2015) Global assessment of arbuscular mycorrhizal fungus diversity reveals very low endemism. Science 349:970-973. https://doi.org/10.1126/science.aab1161

De Deyn GB, Quirk H, Bardgett RD (2011) Plant species richness, identity and productivity differentially influence key groups of microbes in grassland soils of contrasting fertility. Biol Lett 7:75-78. https:// doi.org/10.1098/rsbl.2010.0575

Dias E (1996) Ecologia e sintaxonomia das florestas naturais (Ph.D. Dissertation). University of the Azores, Angra do Heroísmo

Dobo B, Asefa F, Asfaw Z (2016) Diversity of arbuscular mycorrhizal fungi of different plant species grown in three land use types in Wensho and Shebidino districts of Sidama in southern Ethiopia. Adv Biosci Bioeng 4:25. https://doi.org/10.11648/j.abb.20160404. 11

Egerton-Warburton LM, Johnson NC, Allen EB (2007) Mycorrhizal community dynamics following nitrogen fertilization: a cross-site test in five grasslands. Ecol Monogr 77:527-544

Elias RB, Gil A, Silva L et al (2016) Natural zonal vegetation of the Azores Islands: characterization and potential distribution. Phytocoenologia 46:107-123. https://doi.org/10.1127/phyto/2016/ 0132

Faggioli VS, Cabello MN, Grilli G et al (2019) Root colonizing and soil borne communities of arbuscular mycorrhizal fungi differ among soybean fields with contrasting historical land use. Agric Ecosyst Environ 269:174-182. https://doi.org/10.1016/j.agee.2018.10.002

Gaspar C, Borges PA, Gaston KJ (2008) Diversity and distribution of arthropods in native forests of the Azores archipelago. Arquip Life Mar Sci 25:01-30

Gerz M, Bueno CG, Zobel M et al (2016) Plant community mycorrhization in temperate forests and grasslands: relations with edaphic properties and plant diversity. J Veg Sci 27:89-99. https:// doi.org/10.1111/jvs.12338

Göhre V, Paszkowski U (2006) Contribution of the arbuscular mycorrhizal symbiosis to heavy metal phytoremediation. Planta 223:11151122. https://doi.org/10.1007/s00425-006-0225-0

González-Chávez MC, Carrillo-González R, Wright SF, Nichols KA (2004) The role of glomalin, a protein produced by arbuscular mycorrhizal fungi, in sequestering potentially toxic elements. Environ Pollut 130:317-323. https://doi.org/10.1016/j.envpol.2004.01.004

Hartmann M, Frey B, Mayer J et al (2015) Distinct soil microbial diversity under long-term organic and conventional farming. ISME J 9: 1177-1194. https://doi.org/10.1038/ismej.2014.210

Hijri I, Sýkorová Z, Oehl F et al (2006) Communities of arbuscular mycorrhizal fungi in arable soils are not necessarily low in diversity. Mol Ecol 15:2277-2289. https://doi.org/10.1111/j.1365-294X. 2006.02921.x

Hortal J, Borges PAV, Gaspar C (2006) Evaluating the performance of species richness estimators: sensitivity to sample grain size. J Anim Ecol 75:274-287. https://doi.org/10.1111/j.1365-2656.2006.01048. $\mathrm{x}$

$\mathrm{Hu}$ J, Lin X, Wang J et al (2009) Arbuscular mycorrhizal fungus enhances crop yield and P-uptake of maize (Zea mays L.): a field case 
study on a sandy loam soil as affected by long-term P-deficiency fertilization. Soil Biol Biochem 41:2460-2465. https://doi.org/10. 1016/j.soilbio.2009.09.002

IBM Corp (2013) IBM SPSS Statistics for Windows, Version 22.0. IBM Corp, Armonk, NY

Jamshidi S, Behm JE, Eveillard D et al (2015) Using hybrid automata modelling to study phenotypic plasticity and allocation strategies in the plant mycorrhizal mutualism. Ecol Model 311:11-19. https:// doi.org/10.1016/j.ecolmodel.2015.04.021

Jansa J, Mozafar A, Anken T et al (2002) Diversity and structure of AMF communities as affected by tillage in a temperate soil. Mycorrhiza 12:225-234. https://doi.org/10.1007/s00572-002-0163-z

Jansa J, Mozafar A, Kuhn G et al (2003) Soil tillage affects the community structure of mycorrhizal fungi in maize roots. Ecol Appl 13: 1164-1176

Jansa J, Wiemken A, Frossard E (2006) The effects of agricultural practices on arbuscular mycorrhizal fungi. Geol Soc Lond Spec Publ 266:89-115. https://doi.org/10.1144/GSL.SP.2006.266.01.08

Jeffries P, Gianinazzi S, Perotto S et al (2003) The contribution of arbuscular mycorrhizal fungi in sustainable maintenance of plant health and soil fertility. Biol Fertil Soils 37:1-16

Johnson NC, Tilman D, Wedin D (1992) Plant and soil controls on mycorrhizal fungal communities. Ecology 73:2034-2042. https://doi. org/10.2307/1941453

Kawahara A, Ezawa T (2013) Characterization of arbuscular mycorrhizal fungal communities with respect to zonal vegetation in a coastal dune ecosystem. Oecologia 173:533-543. https://doi.org/10.1007/ s00442-013-2622-y

Kim Y-C, Gao C, Zheng Y et al (2015) Arbuscular mycorrhizal fungal community response to warming and nitrogen addition in a semiarid steppe ecosystem. Mycorrhiza 25:267-276. https://doi.org/10.1007/ s00572-014-0608-1

Kivlin SN, Hawkes CV, Treseder KK (2011) Global diversity and distribution of arbuscular mycorrhizal fungi. Soil Biol Biochem 43:2294 2303. https://doi.org/10.1016/j.soilbio.2011.07.012

Köhl L, Oehl F, van der Heijden MGA (2014) Agricultural practices indirectly influence plant productivity and ecosystem services through effects on soil biota. Ecol Appl 24:1842-1853. https://doi. org/10.1890/13-1821.1

König S, Wubet T, Dormann CF et al (2010) TaqMan real-time PCR assays to assess arbuscular mycorrhizal responses to field manipulation of grassland biodiversity: effects of soil characteristics, plant species richness, and functional traits. Appl Environ Microbiol 76: 3765-3775. https://doi.org/10.1128/AEM.02951-09

Lazarevic B, Losak T, Manschadi AM (2018) Arbuscular mycorrhizae modify winter wheat root morphology and alleviate phosphorus deficit stress. Plant Soil Environ 64(2018):47-52. https://doi.org/ 10.17221/678/2017-PSE

Lekberg Y, Waller LP (2016) What drives differences in arbuscular mycorrhizal fungal communities among plant species? Fungal Ecol 24: 135-138. https://doi.org/10.1016/j.funeco.2016.05.012

Li L-F, Zhang Y, Zhao Z-W (2007) Arbuscular mycorrhizal colonization and spore density across different land-use types in a hot and arid ecosystem, Southwest China. J Plant Nutr Soil Sci 170:419-425. https://doi.org/10.1002/jpln.200625034

Li X, Gai J, Cai X, et al (2013) Molecular diversity of arbuscular mycorrhizal fungi associated with two co-occurring perennial plant species on a Tibetan altitudinal gradient. Mycorrhiza 24:. doi: https://doi. org/10.1007/s00572-013-0518-7

Lin X, Feng Y, Zhang $\mathrm{H}$ et al (2012) Long-term balanced fertilization decreases arbuscular mycorrhizal fungal diversity in an arable soil in North China revealed by 454 pyrosequencing. Environ Sci Technol 46:5764-5771. https://doi.org/10.1021/es3001695

Lumini E, Orgiazzi A, Borriello R et al (2010) Disclosing arbuscular mycorrhizal fungal biodiversity in soil through a land-use gradient using a pyrosequencing approach. Environ Microbiol. https://doi. org/10.1111/j.1462-2920.2009.02099.x

Mafaziya F, Madawala S (2015) Abundance, richness and root colonization of arbuscular mycorrhizal fungi in natural and semi-natural land use types at upper Hantana. Ceylon J Sci Biol Sci 44:25. https://doi. org/10.4038/cjsbs.v44i1.7338

Magurran AE (2004) Measuring biological diversity. Blackwell Science, Oxford

Martins AM (1993) The Azores-westernmost Europe: where evolution can be caught red-handed. Mus Mun Funchal 2:181-198

Mathimaran N, Ruh R, Jama B et al (2007) Impact of agricultural management on arbuscular mycorrhizal fungal communities in Kenyan ferralsol. Agric Ecosyst Environ 119:22-32. https://doi.org/10. 1016/j.agee.2006.06.004

Melo CD, Luna S, Krüger C et al (2017) Arbuscular mycorrhizal fungal community composition associated with Juniperus brevifolia in native Azorean forest. Acta Oecol 79:48-61. https://doi.org/10.1016/j. actao.2016.12.006

Melo CD, Walker C, Krüger C et al (2019) Environmental factors driving arbuscular mycorrhizal fungal communities associated with endemic woody plant Picconia azorica on native forest of Azores. Ann Microbiol 69:1309-1327. https://doi.org/10.1007/s13213-01901535-x

Melo CD, Walker C, Rodríguez-Echeverría S et al (2014) Species composition of arbuscular mycorrhizal fungi differ in semi-natural and intensively managed pastures in an isolated oceanic island (Terceira, Azores). Symbiosis 64:73-85. https://doi.org/10.1007/s13199-0140303-1

Minggui G, Tang M, Zhang Q et al (2012) Effects of climatic and edaphic factors on arbuscular mycorrhizal fungi in the rhizosphere of Hippophae rhamnoides in the Loess Plateau, China. Acta Ecol Sin 32:62-67. https://doi.org/10.1016/j.chnaes.2011.12.005

Minitab I (2000) Minitab: release 13 for Windows. Minitab Inc., State College, PA

Moora M, Davison J, Öpik M et al (2014) Anthropogenic land use shapes the composition and phylogenetic structure of soil arbuscular mycorrhizal fungal communities. FEMS Microbiol Ecol 90:609-621. https://doi.org/10.1111/1574-6941.12420

Ndoye F, Kane A, Mangaptché N, et al (2012) Changes in land use system and environmental factors affect arbuscular mycorrhizal fungal density and diversity, and enzyme activities in rhizospheric soils of Acacia senegal (L.) Willd. In: Int. Sch. Res. Not. https://www. hindawi.com/journals/isrn/2012/563191/.

Newbold T, Hudson LN, Hill SL et al (2015) Global effects of land use on local terrestrial biodiversity. Nature 520:45-50. https://doi.org/10. 1038/nature14324

Oehl F, Laczko E, Bogenrieder A et al (2010) Soil type and land use intensity determine the composition of arbuscular mycorrhizal fungal communities. Soil Biol Biochem 42:724-738. https://doi.org/10. 1016/j.soilbio.2010.01.006

Oehl F, Sieverding E, Ineichen K et al (2005) Community structure of arbuscular mycorrhizal fungi at different soil depths in extensively and intensively managed agroecosystems. New Phytol 165:273283. https://doi.org/10.1111/j.1469-8137.2004.01235.x

Olden JD (2006) Biotic homogenization: a new research agenda for conservation biogeography. J Biogeogr 33:2027-2039. https://doi.org/ 10.1111/j.1365-2699.2006.01572.x

Öpik M, Moora M, Liira J, Zobel M (2006) Composition of rootcolonizing arbuscular mycorrhizal fungal communities in different ecosystems around the globe: arbuscular mycorrhizal fungal communities around the globe. J Ecol 94:778-790. https://doi.org/10. 1111/j.1365-2745.2006.01136.x

Öpik M, Vanatoa A, Vanatoa E et al (2010) The online database MaarjAM reveals global and ecosystemic distribution patterns in arbuscular mycorrhizal fungi (Glomeromycota). New Phytol 188: 223-241. https://doi.org/10.1111/j.1469-8137.2010.03334.x 
Pozo MJ, Azcón-Aguilar C (2007) Unraveling mycorrhiza-induced resistance. Curr Opin Plant Biol 10:393-398. https://doi.org/10.1016/j. pbi.2007.05.004

QGIS Development Team (2016) QGIS geographic information system. Open Source Geospatial Foundation Project. Retrieved from http:// qgis.osgeo.org

Rillig MC, Mummey DL (2006) Mycorrhizas and soil structure. New Phytol 171:41-53. https://doi.org/10.1111/j.1469-8137.2006. 01750.x

Rodríguez-Echeverría S, Teixeira H, Correia M et al (2017) Arbuscular mycorrhizal fungi communities from tropical Africa reveal strong ecological structure. New Phytol 213:380-390. https://doi.org/10. 1111/nph.14122

Schmidt MH, Thies C, Nentwig W, Tscharntke T (2008) Contrasting responses of arable spiders to the landscape matrix at different spatial scales. J Biogeogr 35:157-166. https://doi.org/10.1111/j.13652699.2007.01774.x

Schneider S, Hartmann M, Enkerli J, Widmer F (2010) Fungal community structure in soils of conventional and organic farming systems. Fungal Ecol 3:215-224. https://doi.org/10.1016/j.funeco.2009.10. 006

Schnoor TK, Lekberg Y, Rosendahl S, Olsson PA (2011) Mechanical soil disturbance as a determinant of arbuscular mycorrhizal fungal communities in semi-natural grassland. Mycorrhiza 21:211-220. https:// doi.org/10.1007/s00572-010-0325-3

Seaby RMH, Henderson PA, Prendergast JR (2004) Community Analysis Package. Version 4.01. Pisces Conservation Ltd., http:// www.pisces-conservation.com

Senés-Guerrero C, Schüßler A (2016) A conserved arbuscular mycorrhizal fungal core-species community colonizes potato roots in the Andes. Fungal Divers 77:317-333. https://doi.org/10.1007/ s13225-015-0328-7

Shi Z, Wang F, Zhang K, Chen Y (2014) Diversity and distribution of arbuscular mycorrhizal fungi along altitudinal gradients in Mount Taibai of the Qinling Mountains. Can J Microbiol 60:811-818. https://doi.org/10.1139/cjm-2014-0416

Smith SE, Facelli E, Pope S, Andrew Smith F (2010) Plant performance in stressful environments: interpreting new and established knowledge of the roles of arbuscular mycorrhizas. Plant Soil 326:3-20. https://doi.org/10.1007/s11104-009-9981-5

Solís-Rodríguez URJ, Ramos-Zapata JA, Hernández-Cuevas L et al (2020) Arbuscular mycorrhizal fungi diversity and distribution in tropical low flooding forest in Mexico. Mycol Prog 19:195-204. https://doi.org/10.1007/s11557-019-01550-x

Steffan-Dewenter I, Nzenberg UM, Rger CB et al (2002) Scaledependent effects of landscape context on three pollinator guilds. Ecology 83:1421-1432

Sun X, Su Y, Zhang Y et al (2013) Diversity of arbuscular mycorrhizal fungal spore communities and its relations to plants under increased temperature and precipitation in a natural grassland. Chin Sci Bull 58:4109-4119. https://doi.org/10.1007/s11434-013-5961-5

Terzopoulou S, Rigal F, Whittaker RJ et al (2015) Drivers of extinction: the case of Azorean beetles. Biol Lett 11:1-4. https://doi.org/10. 1098/rsbl.2015.0273

Triantis KA, Borges PAV, Ladle RJ et al (2010) Extinction debt on oceanic islands. Ecography 33:-285, 294. https://doi.org/10.1111/ j.1600-0587.2010.06203.x

Turrini A, Giovannetti M (2012) Arbuscular mycorrhizal fungi in national parks, nature reserves and protected areas worldwide: a strategic perspective for their in situ conservation. Mycorrhiza 22:81-97. https://doi.org/10.1007/s00572-011-0419-6

van der Gast CJ, Gosling P, Tiwari B, Bending GD (2011) Spatial scaling of arbuscular mycorrhizal fungal diversity is affected by farming practice. Environ Microbiol 13:241-249. https://doi.org/10.1111/j. 1462-2920.2010.02326.x

van der Heijden MGA, Martin FM, Selosse M-A, Sanders IR (2015) Mycorrhizal ecology and evolution: the past, the present, and the future. New Phytol 205:1406-1423. https://doi.org/10.1111/nph. 13288

Velázquez MS, Cabello MN, Barrera M (2013) Composition and structure of arbuscular-mycorrhizal communities in El Palmar National Park, Argentina. Mycologia 105:509-520. https://doi.org/10.3852/ 11-353

Verbruggen E, Toby Kiers E (2010) Evolutionary ecology of mycorrhizal functional diversity in agricultural systems: $\mathrm{AMF}$ in agriculture. Evol Appl 3:547-560. https://doi.org/10.1111/j.1752-4571.2010. 00145.x

Violi HA, Barrientos-Priego AF, Wright SF et al (2008) Disturbance changes arbuscular mycorrhizal fungal phenology and soil glomalin concentrations but not fungal spore composition in montane rainforests in Veracruz and Chiapas, Mexico. For Ecol Manag 254:276-290. https://doi.org/10.1016/j.foreco.2007.08.016

Vos CM, Tesfahun AN, Panis B et al (2012) Arbuscular mycorrhizal fungi induce systemic resistance in tomato against the sedentary nematode Meloidogyne incognita and the migratory nematode Pratylenchus penetrans. Appl Soil Ecol 61:1-6. https://doi.org/10. 1016/j.apsoil.2012.04.007

Wang YY, Vestberg M, Walker C, Hurme T, Zhang X, Lindström K (2008) Diversity and infectivity of arbuscular mycorrhizal fungi in agricultural soils of the Sichuan Province of mainland China. Mycorrhiza 18:59-68. doi.org/10.1007/s00572-008-0161-x

Xiang D, Verbruggen E, Hu Y et al (2014) Land use influences arbuscular mycorrhizal fungal communities in the farming-pastoral ecotone of northern China. New Phytol 204:968-978. https://doi. org/10.1111/nph.12961

$\mathrm{Xu} \mathrm{X}$, Chen C, Zhang Z et al (2017) The influence of environmental factors on communities of arbuscular mycorrhizal fungi associated with Chenopodium ambrosioides revealed by MiSeq sequencing investigation. Sci Rep 7:45134. https://doi.org/10.1038/srep45134

Yang H, Zang Y, Yuan Y et al (2012) Selectivity by host plants affects the distribution of arbuscular mycorrhizal fungi: evidence from ITS rDNA sequence metadata. BMC Evol Biol 12:1

Zangaro W, de Assis RL, Rostirola LV et al (2008) Changes in arbuscular mycorrhizal associations and fine root traits in sites under different plant successional phases in southern Brazil. Mycorrhiza 19:37-45. https://doi.org/10.1007/s00572-008-0202-5

Zar J (1999) Biostatistical analysis 4th edition. Prentice-Hall International, Upper Saddle River, NJ

Zhang S, Li Q, Lü Y et al (2013) Contributions of soil biota to C sequestration varied with aggregate fractions under different tillage systems. Soil Biol Biochem 62:147-156. https://doi.org/10.1016/j. soilbio.2013.03.023

Zheng Y, Chen L, Luo C-Y et al (2016) Plant identity exerts stronger effect than fertilization on soil arbuscular mycorrhizal fungi in a sown pasture. Microb Ecol 72:647-658. https://doi.org/10.1007/ s00248-016-0817-6

Zheng Y, Kim Y-C, Tian X-F et al (2014) Differential responses of arbuscular mycorrhizal fungi to nitrogen addition in a near pristine Tibetan alpine meadow. FEMS Microbiol Ecol 89:594-605. https:// doi.org/10.1111/1574-6941.12361

Publisher's note Springer Nature remains neutral with regard to jurisdictional claims in published maps and institutional affiliations. 